\title{
Sex determination in bees. XXVII. Castes obtained from larvae fed homogenized food in Melipona compressipes (Hymenoptera, Apidae)
}

\author{
VL Maciel-Silva a, b, WE Kerr c \\ Universidade Federal do Maranhäo, Departamento de Biologia, Maranhäo, Brazil
}

(Received 20 December 1988; accepted 20 December 1990)

\begin{abstract}
Summary - One hundred and eighty-three larvae of Melipona compressipes were fed with mixed food collected from 391 cells containing eggs of various ages. Nine recently provisioned cells had an average of $238 \mathrm{mg}$ of food; the maximum quantity of food a cell can receive if completely full averages $308 \mathrm{mg}$. Larvae were reared in wax cups receiving 350,300 and $240 \mathrm{mg}$ of food (control). Death rate was high due to the handling of larvae. In the $350 \mathrm{mg}$ group, 17 workers and 4 queens were obtained and 34 died before the pupal stage. In the $300 \mathrm{mg}$ group, 39 workers and 8 queens pupated and 38 died. In all there were 56 workers and 12 queens. If quality of food were decisive in queen determination, no segregation of queens and workers should occur, as the food was a homogenized mixture. Weight of last larval stage and genetics were the preponderant caste determinants. Below $184.7 \mathrm{mg}$ of last larval weight no queens are produced; above it, a 3 workers to one queen segregation was observed; we therefore conclude that genetics is the ultimate determining factor of caste in Melipona.
\end{abstract}

Melipona / caste determination / genetic factor / food

\section{INTRODUCTION}

lhering (1903) first noted that in the horizontal brood combs of species of the genus Melipona the cells were about the same size, and that from them queens, workers and drones emerged. Kerr (1975; 1987a) proposed that sex in bees is determined by 2 sets of genes, one that acts in the first hours after the egg is laid and an- other set that acts during the last larval period. An important factor in the first set is the xo series of 20 heteroalleles (Kerr, 1987b) that determines ovaries when heterozygous and testes when hemizygous of homozygous.

In Melipona bees, the second set of genes has 2 main genes with 2 alleles each that are involved in the production of juvenile hormone (Kerr et al, 1975) and

\footnotetext{
a Correspondence and reprints.

b Present address : Universidade de São Paulo, Dept Genetics, Faculdade de Medicina, 14049 Ribeirão Preto, SP, Brazil.

c Universidade Federal de Uberlândia, Dept of Biosciences, 38400, Uberlândia, MG, Brazil
} 
that activate the "femaleness" genes. This has been clearly demonstrated by Campos $(1975,1978)$ and Campos et al (1975) in Melipona quadrifasciata. Melipona quadrifasciata bees were studied (Kerr et al, 1966) in an observation hive for the following behavior: oophagy, number of workers that fill a brood cell with food, time spent by a queen eating food and bees that emerged from cells after the queen had eaten worker eggs, and quantity of food ingested. They found that queens were produced when $>150 \mathrm{mg}$ of food was provided; above this amount a ratio of workers to queens of 3:1 emerged from the cells. Camargo et al (1976) raised larvae of 4 species (Melipona quadrifasciata, Melipona rufiventris, Melipona scutellaris and Melipona marginata) with different amounts of food and found that above a given amount specific for each species, a 3:1 worker/queen segregation was produced. However, Darchen and DelageDarchen $(1974,1975)$ working with overfed Melipona beechei proposed that quantity, quality of food or both are the only factors involved in queen and worker determination. Wilde and Beetsma (1982) put forward the proposal that the bees could distribute food of different quality in different cells, thus determining queens. The present work was planned to contribute to our understanding of the problem of caste determination in Melipona by testing the effect of different quality and quantities of food on the determination of queens in Melipona compressipes fasciculata.

\section{MATERIAL AND METHODS}

Twenty-five colonies of Melipona compressipes fasciculata (Apidae) were used. This species of bee is large, larger than Apis mellifera, and is found in Maranhão State, in the northeastern part of Brazil. Its queens lay an average of 40 eggs per day, reaching a maximum rate of 150 eggs per day. Each cell has a total capacity of $0.277 \mathrm{ml}$. The food density is 1.11 . If completely full, a cell can receive a maximum of $308 \mathrm{mg}$ food. Nine cells from a natural comb, before egg eclosion, received an average of $238 \mathrm{mg}$ of food (s d 13); $240 \mathrm{mg}$ was therefore used as a control.

The first step consisted of making wax cups with hoods. Each cup was slightly smaller than Apis mellifera queen cell cups. Food was taken in batches of 20-150 cells from a total of 391 provisioned cells that contained eggs of various ages. The combined food was then placed in a large test tube and shaken. Food was distributed among 3 sets of cells as follows: group 1: 62 cups, provided with $350 \mathrm{mg}$ of homogenized food; group 2: 97 cups provided with $300 \mathrm{mg}$ of homogenized food; group 3: (control for this experimental condition) 24 cells provided with 240 $\mathrm{mg}$ of homogenized food; group 4: (natural control) a comb taken from the hive in June 1988.

The second step consisted of shaking the test tube each time a new cell was filled. After the artificial wax cell received the given amount of food a recently eclosed lanva ( $<20-\mathrm{h}$ old) was deposited on the food and the cell was provided with a wax hood. The entire batch was then placed in a desiccator $(240 \mathrm{~mm}$ inside diameter $\times 310 \mathrm{~mm}$ height) with a saturated solution of $\mathrm{KCl}$ which provided $84 \%$ relative humidity (ASTM, 1951). The desiccator (with the artificial cells) was placed in an incubator at a temperature of $30-33^{\circ} \mathrm{C}$. Castes were easily determined soon after the bee reached the whiteeyed pupa, stage.

Since it is difficult to obtain Melipona material, each larva was weighed twice daily to determine whether the larvae continued eating after they began to spin the cocoon (Maciel-Silva, 1989). The weights were obtained when the larvae finished eating, prior to defecation. Due to unknown reasons many larvae did not eat all the food that was given, which is the reason why the weight of last-stage larvae was preferred to the weight of food deposited in the cups.

\section{RESULTS AND DISCUSSION}

The set of 62 cups with $350 \mathrm{mg}$ of homogenized food produced: 17 workers and 4 queens $\left(\chi^{2}(3: 1)=0.4\right)$ plus 34 larvae that 
died before metamorphosis, 2 males, 4 malformed larvae, and 1 that reached a pupal stage but its caste could not be determined. The maximum capacity of a natural cell is $308 \mathrm{mg}$ of food; thus, $350 \mathrm{mg}$ is an amount which is not found in nature. The 3 heaviest larvae weighed $258.4 \mathrm{mg}$, $257.3 \mathrm{mg}$ and $247.5 \mathrm{mg}$ and became respectively: worker, worker, queen; ie, the heaviest larvae did not develop into queen bees.

The set of 97 cups that received $300 \mathrm{mg}$ of homogenized food produced 39 workers and 8 queens $\left(\chi^{2} 3: 1=1.6\right), 4$ males, 3 malformed larvae, 38 dead larvae, and 5 unidentified larvae.

The lightest last-stage larva that developed into a queen weighed $184.7 \mathrm{mg}$. The 3 heaviest larvae of this group weighed $230.5,230.5$ and $228.2 \mathrm{mg}$ and became queen, worker and worker bee, respectively.

The set of 24 larvae fed $240 \mathrm{mg}$ produced 0 queens, 19 workers, 3 males, 1 malformed larva, and 1 dead larva. The heaviest larva of this batch weighed 178.6 $\mathrm{mg}$ and became a worker bee.

The brood comb collected in July 1988 produced 7 queens, 84 workers and 0 male bees.

Counting all bees with a larval weight of $\geq 184 \mathrm{mg}$ in the first and second set resulted in a total number of workers and 12 queens $\left(\chi^{2} \quad 3: 1=0.4\right)$.

Splitting our sample into 2 groups: 184.7-216 and 216.1-247.5, 20 workers and 6 queens $\left(\chi^{2} 3: 1=0.05\right)$ in the first group, 10 workers and 5 queens $\left(\chi^{2}=\right.$ 0.56 ) in the second group, were found: $216.1 \mathrm{mg}$ was the average between the heaviest and the lighest queen larvae. Therefore, we concluded that overfeeding did not cause determination of castes.
Darchen and Delage-Darchen (1974, 1975) and Wilde and Beetsma (1982) advanced the idea that workers deposited a different quality of food in the cells from which queens emerged. However, the results of our experiments do not support the hypothesis that different food is deposited in different cell cups. Our results, however, support the hypothesis of Kerr (1975) that, in the presence of sufficient food in the cell, caste differentiation in Melipona compressipes is caused by genetic factors. Kerr proposes a model of gene action in which the queens are heterozygous $\left(x_{a}{ }^{1}\right)$ $\left.x_{a}{ }^{1} ; x_{b}{ }^{1 /} x_{b}{ }^{2}\right)$ for 2 genes that control juvenile hormone production and, in the heterozygous condition, initiates femaleness. Males are hemizygous for 2 of the 4 alleles, while workers are homozygous for one or 2 alleles, producing JH deficiency. Therefore their eyes, head proportions, thorax and appendices, abdomen, and cuticle, are all masculine in form. Thus, the worker caste and males in meliponids are produced by a suppression of the action of femaleness genes.

\section{CONCLUSION}

Mortality was much higher in the 2 overfed groups ( 300 and $350 \mathrm{mg}$ ) than in the $240 \mathrm{~g}$ group for 2 reasons: a) the overfed group pupated later and was, therefore, manipulated more intensely; b) bees of this species provide cells with 150 to $270 \mathrm{mg}$ of food; they do not reach $300 \mathrm{mg}$. Therefore higher mortality at those levels may also be due to unknown physiological effects of ingesting a large quantity of food.

\section{ACKNOWLEDGMENTS}

This work was financed by $\mathrm{CNPq}$ (Brazil), (Grant No 500225/88.5 to WE Kerr and Scientific Initia- 
tion Fellowship to VL Maciel-Silva). RE Page Jr and four anonymous reviewers corrected the English and presented helpful comments on the manuscript. E Tarouco kindly translated the French summary.

Résumé - Détermination du sexe chez
les abeilles. XXVII. Castes obtenues à
partir de larves de Melipona compres-
sipes ayant reçu une nourriture homogénéisée. Cent quatre vingt trois larves de Melipona compressipes ont reçu une nourriture mélangée, prélevée dans 391 cellules d'ouvrières après la ponte de l'œuf et juste avant l'éclosion de la larve. Neuf cellules naturelles, qui venaient d'être approvisionnées, contenaient en moyenne 238 $\mathrm{mg}$ de nourriture. La quantité maximale qu'une cellule entièrement pleine peut contenir est d'environ $308 \mathrm{mg}$. Des cupules en cire ont été réparties en 3 séries : chaque cupule a reçu respectivement 350 $\mathrm{mg}, 300 \mathrm{mg}$ et $240 \mathrm{mg}$ de nourriture, la $3^{e}$ série servant de témoin. Le taux de mortalité des larves a été élevé en raison des manipulations subies. La 1re série a fourni 17 ouvrières et 4 reines (mais 34 larves sont mortes avant le stade nymphe). Les 2 larves les plus lourdes au dernier stade pesaient $258,4 \mathrm{mg}$ et $257,3 \mathrm{mg}$ et donnèrent des ouvrières. La $2^{e}$ série a donné 39 ouvrières et 8 reines (38 larves sont mortes). Cela fait au total 56 ouvrières et 12 reines. Si la qualité de la nourriture constituait le facteur décisif de la formation des reines, il ne devrait pas y avoir de différentiation entre reines et ouvrières, puisque toutes les larves avaient reçu la même nourriture homogénéisée. Le poids du dernier stade larvaire et la génétique sont les facteurs prédominants dans la détermination des castes. Lorsqu'au dernier stade la larve pèse moins de $184,7 \mathrm{mg}$, aucune reine n'est formée. Au-dessus de ce poids, on observe une différentiation entre ouvrières et reines dans le rapport de 3 à 1. Cela signifie que le facteur génétique est décisif dans la détermination des castes chez les mélipones.

Melipona / détermination des castes / facteur génétique / facteur trophique

Zusammenfassung - Geschlechtbe-
stimmung bei Bienen. XXVII. Kasten von
Melipona compressipes, entstanden
aus Larven, die mit homogenisiertem Futter ernährt worden waren. 183 Larven von Melipona compressipes wurden mit gemischtem Futter ernährt, das aus 391 Zellen nach der Eilage bis kurz vor dem Ausschlüpfem der Larven gesammelt worden war. Neun Zellen, die erst kürzlich mit Futter versorgt worden waren, enthielten im Durchschnitt $238 \mathrm{mg}$ Futter. Die größte Menge, die eine vollständig gefülite Zelle aufnehmen kann, betrug im Mittel $308 \mathrm{mg}$ Futter. Ein Satz von Wachsbechern erhielt $350 \mathrm{mg}$, ein anderer $300 \mathrm{mg}$ und die Kontrollgruppe $240 \mathrm{mg}$ Futter. Die Sterblichkeitsrate war in Folge der Manipulation mit den Larven hoch.

Aus der Gruppe mit 350 mg entstanden 17 Arbeiterinnen und 4 Königinnen, aber 34 starben vor Erreichung des Puppenstadiums. Die zwei schwersten unter den letzten Larvenstadien wogen $258,4 \mathrm{mg}$ und $257,3 \mathrm{mg}$ und entwickelten sich zu Arbeiterinnen. Aus der Gruppe mit $300 \mathrm{mg}$ verpuppten sich 39 Arbeiterinnen und 8 Königinnen, während 38 starben. Zusammen sind 56 Arbeiterinnen und 12 Königinnen entstanden. Wäre die Qualität des Futters der entscheidende Faktor bei der Königinnenentstehung, so dürfte es keine Aufspaltung in Königinnen und Arbeiterinnen geben, denn alle Larven erhielten dieselbe homogenisierte Futtermischung. Das Gewicht des letzten Larvenstadiums und Genetik waren die vorrangigen Faktoren bei der Kastenbestimmung: 
Unterhalb eines Gewichtes des letzten Larvenstadiums von $184,7 \mathrm{mg}$ wurden keine Königinnen erzeugt. Oberhalb dieses $\mathrm{Ge}$ wichtes wurde eine Aufspaltung im Verhältnis von 3 Arbeiterinnen und einer Königin beobachtet. Das bedeutet, daß Genetik der entscheidende Faktor bei der Kastenbestimmung bei Melipona ist.

\section{Melipona / Kastenbestimmung / Gene- tik / Futter}

\section{REFERENCES}

ASTM (1951) Recommended Practice for Maintaining Constant Relative Humidity by Means of Aqueous Solutions. ASTM designation: $\mathrm{E}$ 104-51. American Society for Testing Materials (ASTM) Philadelphia, PA, USA

Camargo CA, de Almeida MG, de Nates Parra MG, Kerr WE (1976) Genetic of sex determination in bees. IX. Frequence of queens and workers from larvae under controlled condition (Hym Apidae). J Kans Entomol Soc 49, 120-125

Campos LAO (1975) Determinação de castas no gênero Mel ipona (Hymenoptera Apidae). Papel do Hormónio Juvenil. M Sc Thesis Dept de Genética e Matemática Aplicada e Biologia, Faculdade de Medicina de Ribeirão Preto, SP, Brazil

Campos LAO (1978) Sex determination in bees. VI. Effect of a juvenile hormone analogue in males and females of Melipona quadrifasciata (Apidae). J Kans Entomol Soc 51(2), 228234

Campos LAO, Velthuis HC, Velthuis MH (1975) Sex determination in bees. VIII. Effect of juvenile hormone analogue in caste determi- nation of Melipona. Naturwissenschaften 62 , 98-99

Darchen R, Darchen-Delage B (1974) Nouvelles expériences concernant le déterminisme des castes chez les Mélipones (Hyménoptères Apidés). CR Séances Acad Sci (Paris) 278, 907-910

Darchen RG, Delage-Darchen (1975) Sur le déterminisme des castes chez les Mélipones (Hymenoptera Apidé). Bull Biol Fr Belg cx-1, 91-109

Ihering $H$ Von (1903) Biologia da abelhas melliferas do Brasil. Bol Agric $32(5,6), 32(7,8)$, $649-714$ (1930); transl Zool Jahrb 19, 179287

Kerr WE (1975) Evolution of population structure in bees (Apidae). Genetics 795, 73-94

Kerr WE (1987a) Biologia, manejo e genética de Melipona compressipes fasciculata Smith (Hymenoptera, Apidae). Thesis São Luis, Maranhāo, Brazil

Kerr WE (1987b) Sex determination in bees. $X X I$. Number of xo-heteroalleles in a natural population of Melipona compressipes fasciculata (Hymenoptera Apidae). Insectes Soc 34(4), 274-279

Kerr WE, Stort AC, Montenegro MJ (1966) Importância de alguns fatores ambientais na determinação das castas do gênero Melipona. An Acad Bras Ciências 38(1), 149-168

Kerr WE, Akahira Y, Camargo CA de (1975) Sex determination in bees. IV. Genetic control of juvenile hormone production in Melipona quadrifasciata (Apidae). Genetics 81, 749756

Maciel-Silva VL (1989) Tecelagem do casulo em Melipona compressipes fasciculata durante a fase alimentar. Ciênc Cult (Sao Paulo) 41 (6), 601-602

Wilde J, de Beetsma J (1982) The physiology of caste development in social insects. $A d v / n$ sect Physiol 16, 167-246 